\title{
In vitro methane and gas production characteristics of Eragrostis trichopophora substrate supplemented with different browse foliage
}

\author{
Abubeker Hassen ${ }^{\mathrm{A}} \mathrm{B}$, Jacobus Johannes Francois Theart ${ }^{\mathrm{A}}$, Willem Adriaan van \\ Niekerk ${ }^{A}$, Festus Adeyemi Adejoro ${ }^{A}$ and Belete Shenkute Gemeda ${ }^{A}$ \\ A Department of Animal and Wildlife Sciences, University of Pretoria, South Africa. \\ ${ }^{\text {B } C o r r e s p o n d i n g ~ a u t h o r . ~ E m a i l: ~ A b u b e k e r . h a s s e n @ u p . a c . z a ~}$
}

\begin{abstract}
An in vitro gas production study was conducted to evaluate the potential of six browse species (high, medium and low condensed tannin concentrations) collected from the Kalahari Desert as antimethanogenic additives to an Eragrostis trichopophora-based substrate. The browse species studied were Acacia luederitzii, Monechma incanum, Acacia erioloba, Acacia haematoxylon, Olea europaea and Acacia mellifera. The edible forage dry matter of the browse species were incubated with Eragrostis trichopophora in a $30: 70$ $(w / w)$ ratio by adding $40 \mathrm{~mL}$ of a buffered rumen fluid at $39^{\circ} \mathrm{C}$ for $48 \mathrm{~h}$. Gas and methane production at different time intervals after incubation were determined whereas the volatile fatty acids concentration was evaluated after $48 \mathrm{~h}$. Acacia luederitzii and $M$. incanum foliage decreased methane production by more than $50 \%$, but simultaneously decreased digestibility, and rumen fermentation parameters such as volatile fatty acids concentration. Tannin extracts from A. luederitzii could possibly be used as a dietary alternative to reduce methane production; however, there is a need to determine an optimum level of inclusion that may not compromise the efficiency of rumen fermentation and overall digestibility of the diet.
\end{abstract}

Additional keywords: digestibility, tannin.

\section{Introduction}

Ruminants are major contributors to biogenic methane $\left(\mathrm{CH}_{4}\right)$ production, and it has been estimated that the reduction of $\mathrm{CH}_{4}$ formation from domesticated ruminants could contribute to stabilising atmospheric $\mathrm{CH}_{4}$ concentrations (Gibbs et al. 1989; Crutzen 1995; Johnson and Johnson 1995). Reducing enteric $\mathrm{CH}_{4}$ has become a focus of animal nutrition, especially in countries where agriculture is a major economic enterprise. There are currently no robust, reproducible and economically viable methods for reducing $\mathrm{CH}_{4}$ emissions from ruminants grazing on pastures. Manipulating the rumen microbial ecosystem to enhance digestibility of fibrous feeds, reduce $\mathrm{CH}_{4}$ emission and nitrogen (N) excretion, and also improve performance, are some of the most important goals of animal nutritionists. 
However, researchers manipulating the rumen microbial ecosystem to enhance digestibility of fibrous feeds, and reduce $\mathrm{CH}_{4}$ emission and $\mathrm{N}$ excretion by ruminants have failed to find an effective chemical inhibitor of ruminal $\mathrm{CH}_{4}$ formation whose efficacy will persist for several days (Clapperton 1977; Van Nevel and Demeyer 1996). The only effective chemical inhibitor widely in use is ionophores, which inhibits the formation of free hydrogen by species that provides hydrogen to the methanogens (Nagaraja et al. 1997), and subsequently decrease $\mathrm{CH}_{4}$ emissions by up to $25 \%$ (Van Nevel and Demeyer 1996), but the overall effect of ionophores appears to be inconsistent (Nagaraja et al. 1997). There is a need for feed additives with the potential to reduce ruminal methanogenesis. Extensive screening of plants and plant extracts that exhibit $\mathrm{CH}_{4}$-reducing properties have been conducted (Kamra et al. 2006; Bodas et al. 2008; García-González et al. 2008; Soliva et al. 2008). Tannins are among the compounds considered promising in $\mathrm{CH}_{4}$ reduction (Patra and Saxena 2010). In tropical herbaceous forages like trees and shrub species, there are appreciable amounts of tannins and other phenolic compounds in their foliage, which may reduce $\mathrm{CH}_{4}$ production (Martin et al. 2010).

However, the effectiveness of plants and plant extracts that have high levels of saponins, flavonoids and tannins, varies depending on the molecular weight, type and concentration of these compounds (Patra et al. 2006). Some in vitro studies combined additives with single substrates such as grain meals (Callaway and Martin 1996; Carro and Ranilla 2003; Pellikaan et al. 2011) or hay (Lourenco et al. 2008; Goel et al. 2009) to reduce $\mathrm{CH}_{4}$ production whereas other studies used a mixed basal substrate, such as alfalfa hay (Wang et al. 2000; Busquet et al. 2005) or grass hay (Lila et al. 2003; Hu et al. 2005; Guo et al. 2008) combined with a concentrate in evaluating $\mathrm{CH}_{4}$ reduction. Few reports exist in which the effects of additives were studied in combination with different substrates within a single experiment to reduce enteric $\mathrm{CH}_{4}$ emissions. Research to identify new compounds or novel uses for existing natural products to reduce $\mathrm{CH}_{4}$ is expensive, but is essential to identify new active compounds given the wide range of molecular diversity in these products (Borris 1996). The aim of this study was to evaluate the effect of supplementing $E$. trichopophora grass with browse species containing high, medium and low levels of tannins at $70: 30$ ratio with or without polyethylene glycol (PEG), on $\mathrm{CH}_{4}$ production and digestibility. In doing so, we can possibly select browse species with the potential to decrease $\mathrm{CH}_{4}$ production in extensive farming systems.

\section{Materials and methods}

\section{Selection of the browse species}

One kilogram of edible foliage sample of six browse species were sampled in the Kalahari $\left(26^{\circ} 46.610^{\prime} \mathrm{S}, 22^{\circ} 34.557^{\prime} \mathrm{E}\right)$ area situated in the Northern Cape Province of South Africa between March and April 2012. These species (M. incanum, A. luederitzii, A. erioloba, A. haematoxylon, $O$. europaea and $A$. mellifera) were analysed for total tannin and condensed tannin (CT) concentrations and based on its tannin concentrations (data not included) were selected to be used in this study. Two browse species each representing a low, medium and high tannin concentration group, were selected for inclusion and incubated with the substrate E. trichopophora in a $30: 70$ ratio (w/w). 


\section{In vitro gas production measurement}

Collection of rumen fluid from donor sheep. Rumen fluid was collected before the morning feeding from two rumen-cannulated Merino wethers fed alfalfa hay ad libitum.

Approximately $500 \mathrm{~mL}$ of the rumen fluid was collected from each donor animal, mixed, strained through four layers of cheesecloth and transferred inside a pre-warmed thermos flask to the laboratory (Grant and Mertens 1992). After blending, the rumen fluid was transferred to a large glass beaker inside a $39^{\circ} \mathrm{C}$ water bath being continuously purged with carbon dioxide and under continuous stirring as recommended by Goering and Van Soest (1970). Thereafter, the required volume of rumen fluid was added to the buffer solution in the respective incubation bottles; $15 \mathrm{~mL}$ of rumen fluid to $25-\mathrm{mL}$ parts of buffer solution.

Buffer media preparation, sample incubation and gas measurement. The buffer solution, macro and micro mineral solution was prepared as described in Goering and Van Soest (1970) with the modifications suggested by Mould et al. (2005). A semi-automated system was used to measure gas production through in vitro incubation at $39^{\circ} \mathrm{C}$, according to the method described by Theodorou et al. (1994). The system consists of a digital data tracker (Tracker 220 series indicators, Omega Engineering, Inc., Laval, QC, Canada), connected to a pressure transducer (PX4200-015GI from Omega Engineering, Inc.) with a needle tip. Approximately $400 \mathrm{mg}$ of respective substrate was weighed into a $120-\mathrm{mL}$ serum bottle. Thereafter, $40 \mathrm{~mL}$ of rumen fluid and buffer media was added under a stream of carbon dioxide to each serum bottle and then closed with a rubber stopper and a crimp seal cap. A needle was inserted through the rubber stopper of each serum bottle for $\sim 5 \mathrm{~s}$ to release the small amount of gas that might have built up and create the starting point for incubation. All serum bottles were returned to the incubator $\left(39^{\circ} \mathrm{C}\right)$ and the rotary shaker was turned on at $120 \mathrm{rpm}$. Gas pressure was taken at $2 \mathrm{~h}, 4 \mathrm{~h}, 8 \mathrm{~h}, 12 \mathrm{~h}, 24 \mathrm{~h}, 48 \mathrm{~h}$ and $72 \mathrm{~h}$ after incubation. To quantify gas production derived from the culture medium and the ruminal inoculums, two blanks were included in every analysis. Two replicates of the same browse and four different cycles were executed for every browse sample studied. The pressure and volume values were registered and added to the values of the previous readings. Therefore, the cumulative pressure and volume of the fermentation gases could be obtained. However, fermentation was terminated after $72 \mathrm{~h}$ by removing the serum bottles from the incubator and placing them on ice. After opening the bottle, $\mathrm{pH}$ readings were taken and the supernatants were collected and stored for volatile fatty acids (VFA) analyses.

\section{Short-chain VFA analyses}

From each incubation bottle, $5 \mathrm{~mL}$ of supernatant was collected and stored for analysis of VFA. Samples were centrifuged in a Sorvall centrifuge (SL-50 T, $8 \times 50 \mathrm{~mL}$ ) at $25000 \mathrm{~g}$ for 15 $\min$ at $4^{\circ} \mathrm{C}$ and a part of the supernatant was transferred to a micro-centrifuge tube (capacity $1.5 \mathrm{~mL}$ ) containing meta-phosphoric acid (250 g/L). The standard VFA mixture consisted of acetic, propionic, butyric, isobutyric, valeric and isovaleric acids was used as internal standard, and was treated in the same manner as that for the sample. The VFA in the test sample was analysed using a gas chromatograph with flame ionisation detector (FID) analyser, calibrated against the standard. The final concentration was reported after deducting the corresponding blank values. 


\section{Determination of in vitro organic matter digestibility (IVOMD)}

The procedure used in this study was according to that of Tilley and Terry (1963), as modified by Engels and Van der Merwe (1967), which involves two digestion phases. During the first digestion phase, feed samples (200 mg) were incubated in triplicate under anaerobic conditions with rumen liquor for $48 \mathrm{~h}$ at $39^{\circ} \mathrm{C}$ with the inclusion of blanks and standards in every batch of incubation. This was followed by a 48-h acid pepsin digestion phase at $39^{\circ} \mathrm{C}$ under anaerobic conditions. Following the $96-\mathrm{h}$ incubation, the residual plant materials were collected and oven-dried at $105^{\circ} \mathrm{C}$ for $12 \mathrm{~h}$. Ash contents were determined by combustion $\left(550^{\circ} \mathrm{C}\right.$ for $2 \mathrm{~h}$ ) (Engels and Van der Merwe 1967). Metabolisable energy was determined by using the equation $\mathrm{ME}=0.016 *$ IVOMD suggested by McDonald et al. (2002) for roughages.

\section{Methane production measurements}

Methane production was measured from duplicate bottles incubated for each substrate by taking gas samples at $2 \mathrm{~h}, 12 \mathrm{~h}, 24 \mathrm{~h}$, and $48 \mathrm{~h}$ after incubation and analysing the $\mathrm{CH}_{4}$ concentration using a gas chromatograph (8610C BTU gas analyser gas chromatograph system; SRI Instruments $\mathrm{GmbH}$, Bad Honnef, Germany) calibrated using standard analytical gas. Gas produced from each bottle at various times was recorded and samples of the gas were taken using a Hamilton syringe and $1 \mathrm{~mL}$ of sampled gas produced was injected manually into the gas chromatograph. Two blanks were included for correction of $\mathrm{CH}_{4}$ produced from the inoculum in each cycle and a total of two cycles were executed. The $\mathrm{CH}_{4}$ concentration that was measured at each time interval was related to total gas volume to determine its concentration (Tavendale et al. 2005) and converted later into energy and mass values using $39.54 \mathrm{~kJ} / \mathrm{L} \mathrm{CH}_{4}$ and $0.716 \mathrm{mg} / \mathrm{mL} \mathrm{CH}$ factors, respectively (Santoso et al. 2007).

\section{Statistical analyses}

Grass hay nutrient composition, gas and $\mathrm{CH}_{4}$ production and VFA concentrations were statistically analysed using the GLM option of SAS (2010), and mean differences among foliage species were determined using Duncan's multiple-range test.

\section{Results and discussion}

\section{Chemical composition}

The chemical composition of E. trichopophora used as test feed have the following composition: ash (33.1 g/kg DM), crude protein ( $34.3 \mathrm{~g} / \mathrm{kg} \mathrm{DM})$, ether extract ( $9.5 \mathrm{~g} / \mathrm{kg} \mathrm{DM})$, neutral detergent fibre (794.9 g/ $\mathrm{kg} \mathrm{DM})$, acid detergent fibre (477.7 g/kg DM), acid detergent fibre $(67.9 \mathrm{~g} / \mathrm{kg} \mathrm{DM})$ and neutral detergent-insoluble $\mathrm{N}(21 \mathrm{~g} / \mathrm{kg} \mathrm{DM})$. Eragrostis trichopophora is low in crude protein with a high neutral detergent fibre concentration. 
Table 1. Volumes (mL/g DM) of gas production from the studied browse and shrubs supplemented to grass hay at a ratio of $30: 70$ with or without polyethylene glycol (PEG)

Means with different lower-case letters within a column are significantly $(P<0.001)$ different. Means with different upper-case letters in rows within each incubation time are significantly $(P<0.05)$ different. No PEG, denotes presence of tannin; PEG, denotes absence of tannin

\begin{tabular}{|c|c|c|c|c|c|c|c|c|c|}
\hline \multirow[b]{3}{*}{ Species } & \multirow[b]{3}{*}{ Tannin level } & \multicolumn{8}{|c|}{ Gas production (mL/g DM) } \\
\hline & & \multicolumn{2}{|c|}{$2 \mathrm{~h}$} & \multicolumn{2}{|c|}{$12 \mathrm{~h}$} & \multicolumn{2}{|c|}{$24 \mathrm{~h}$} & \multicolumn{2}{|c|}{$48 \mathrm{~h}$} \\
\hline & & PEG & No PEG & PEG & No PEG & PEG & No PEG & PEG & No PEG \\
\hline Acacia luederitzii & High & 22.1aA & $5.2 \mathrm{~dB}$ & 77.1abA & $39.8 \mathrm{~dB}$ & $166.2 \mathrm{aA}$ & $115.5 \mathrm{eA}$ & 227.9aA & $147.7 \mathrm{cB}$ \\
\hline Monechma incanum & High & $18.2 \mathrm{bA}$ & $9.5 \mathrm{cB}$ & $79.4 a A$ & $50.1 b B$ & 163.9aA & $134.2 \mathrm{cB}$ & $212.1 \mathrm{bA}$ & $161.7 \mathrm{~dB}$ \\
\hline Acacia erioloba & Medium & 21.3aA & $17.5 \mathrm{aB}$ & $73.5 \mathrm{bA}$ & $54.5 \mathrm{abB}$ & $141.0 \mathrm{bA}$ & $131.4 \mathrm{~dB}$ & $188.6 \mathrm{dA}$ & $160.3 \mathrm{~dB}$ \\
\hline Acacia haematoxylon & Medium & 19.6abA & $13.0 \mathrm{bB}$ & 78.1abA & $56.3 \mathrm{aB}$ & $161.2 \mathrm{aA}$ & $132.3 \mathrm{~dB}$ & 197.1cA & $177.2 \mathrm{bB}$ \\
\hline Olea europaea & Low & $11.8 \mathrm{~dB}$ & 17.0aA & $58.8 \mathrm{cA}$ & $50.3 \mathrm{bB}$ & $125.6 \mathrm{cA}$ & $145.5 b B$ & $164.4 f \mathrm{~A}$ & $157.8 \mathrm{cbB}$ \\
\hline Acacia mellifera & Low & $14.7 \mathrm{cA}$ & $12.0 \mathrm{cbB}$ & $55.0 \mathrm{cA}$ & $44.5 \mathrm{cB}$ & $120.9 \mathrm{cA}$ & $143.6 \mathrm{bB}$ & $179.8 \mathrm{eA}$ & $163.8 \mathrm{cbB}$ \\
\hline Eragrostis trichopophora & No tannin & $4.4 \mathrm{eA}$ & $3.5 \mathrm{~dB}$ & $57.2 \mathrm{cA}$ & $45.3 c B$ & $157.5 \mathrm{aA}$ & $156.0 \mathrm{aA}$ & $221.8 \mathrm{aA}$ & $212.9 a B$ \\
\hline $\begin{array}{l}\text { s.e.m. } \\
P\end{array}$ & & $\begin{array}{c}0.39 \\
<0.001\end{array}$ & $\begin{array}{c}0.34 \\
<0.001\end{array}$ & $\begin{array}{c}0.66 \\
<0.001\end{array}$ & $\begin{array}{c}0.62 \\
<0.001\end{array}$ & $\begin{array}{c}1.85 \\
<0.001\end{array}$ & $\begin{array}{c}1.00 \\
<0.001\end{array}$ & $\begin{array}{c}1.01 \\
<0.001\end{array}$ & $\begin{array}{c}1.33 \\
<0.001\end{array}$ \\
\hline
\end{tabular}




\section{In vitro gas production and IVOMD}

There were significant differences $(P<0.001)$ among the different browses included in the grass-browse substrate in terms of cumulative gas production when incubated with or without PEG as a tannin binder (Table 1). The effects of tannin ('PEG' versus 'No PEG') in the grass-browse substrates, showed that gas production was reduced by $40 \mathrm{~mL}$ and $65 \mathrm{~mL}$ in substrate with high CT browse, $19 \mathrm{~mL}$ and $24 \mathrm{~mL}$ in substrate with medium CT browse and 9 $\mathrm{mL}$ and $11 \mathrm{~mL}$ in low CT browse after $24 \mathrm{~h}$ and $48 \mathrm{~h}$ incubation, respectively. Acacia luederitzii and $M$. incanum (high tannin) decreased gas production by an average of $20 \%$ whereas $A$. erioloba and $A$. haematoxylon (medium tannin) decreased gas production by an average of $15.5 \%$ whereas $O$. europaea and $A$. mellifera (low tannin) reduced gas production by $7.3 \%$ after $24 \mathrm{~h}$ of in vitro incubation.

\section{Volatile fatty acid concentration}

Incubation of the grass with high ( $A$. luederitzi and $M$. incanum) and medium ( $A$. erioloba and $A$. haematoxylon) CT-containing browse substrate resulted in decreased total VFA production whereas incubation of the grass substrate with low CT-containing browses ( $A$. melifera and O. europa) led to increased total VFA production. However, the inclusion of PEG as a tannin binder resulted in an increase in VFA concentration for each browse-grass substrate (Table 2). The acetic, propionic, iso butyric, butyric, and valeric acid concentrations differed among the browse species. Supplementation of browse with high and medium tannin concentration to Eragrostis grass hay decreased acetatic acid production, which is a major product of fibre fermentation but no difference was noted in grass supplemented with browse species having low tannin concentrations. The effects of CT on ruminal VFA concentration and composition vary among studies, depending on dose and source of CT (Bhatta et al. 2005). In the study of Khiaosa-Ard et al. (2009) using a rumen simulation technique, a decrease in the acetate : propionate ratio was reported when $\mathrm{CT}$ extract from $A$. mearnsii was fed to animals. Condensed tannins resulted in a decrease in acetate production when compared with the PEG-included incubations in the grass-browse substrates that contain high and medium CT concentrations whereas supplementation of browse species with low CT concentrations resulted in increased acetate production without PEG inclusion. Beauchemin et al. (2007) reported that increasing levels of tannins up to 20 $\mathrm{g} / \mathrm{kg}$ DM tended to decrease the ruminal total VFA concentration and the acetate : propionate ratio in cattle.

In this study, the acetate : propionate ratio decreased when no PEG was included (data not reported in Table 3). In contrast, Carulla et al. (2005), Beauchemin et al. (2007) and KhiaosaArd et al. (2009) reported that VFA concentrations remained unchanged, but that the molar proportion of propionate increased in sheep fed $A$. mearnsii containing $\mathrm{CT}$. In general, molar ratios of the principal VFA are not changed by feeding CT-containing forages (Waghorn and Shelton 1997; Puchala et al. 2005), but their concentrations in rumen liquor are often reduced, probably a reflection of a larger rumen pool size and a slower rate of VFA production from a slower rate of fibre digestion (Waghorn et al. 1994). The results from this study indicate that the concentration of total tannins and CT is negatively related to VFA production and particularly acetate, thus compromising the availability of nutrient for microbial synthesis. 
Table 2. Total and individual volatile fatty acid $(\mathrm{mmol} / \mathrm{L})$ concentration in the supernatant after $72-\mathrm{h}$ incubation of $400 \mathrm{mg}$ DM of browses with or without polyethylene glycol (PEG)

Means with different lower-case letters within a column are significantly $(P<0.05)$ different. Means with different upper-case letters in rows within each incubation time are significantly $(P<0.05)$ different. No PEG, denotes presence of tannin; PEG, denotes absence of tannin. IVOMD, in vitro organic matter digestibility; VFA, volatile fatty acid

\begin{tabular}{|c|c|c|c|c|c|c|c|c|c|c|c|c|c|c|}
\hline \multirow[b]{2}{*}{ Species } & \multicolumn{2}{|c|}{ Acetic } & \multicolumn{2}{|c|}{ Propionic } & \multicolumn{2}{|c|}{ Iso butyric } & \multicolumn{2}{|c|}{ Butyric } & \multicolumn{2}{|c|}{ Valeric } & \multicolumn{2}{|c|}{ Total VFA mmol/L } & \multicolumn{2}{|c|}{ IVOMD } \\
\hline & PEG & NO PEG & PEG & No PEG & PEG & No PEG & PEG & No PEG & PEG & No PEG & PEG & No PEG & PEG & No PEG \\
\hline Acacia luederitzii & $51.91 \mathrm{eA}$ & $49.19 \mathrm{~dB}$ & $12.63 \mathrm{eB}$ & $13.91 \mathrm{cA}$ & $1.44 \mathrm{eA}$ & $1.41 \mathrm{dA}$ & $5.06 \mathrm{fA}$ & $4.74 \mathrm{fB}$ & $1.71 \mathrm{eA}$ & $1.78 \mathrm{cA}$ & 72.76fA & $71.04 \mathrm{gB}$ & $58.79 \mathrm{aA}$ & $47.51 \mathrm{~dB}$ \\
\hline Monechma incanum & $59.04 \mathrm{aA}$ & $48.9 \mathrm{~dB}$ & $15.72 \mathrm{aA}$ & $13.44 \mathrm{~dB}$ & $1.70 \mathrm{bA}$ & $1.47 \mathrm{cB}$ & $7.15 \mathrm{aA}$ & $5.60 \mathrm{eB}$ & $2.15 \mathrm{aA}$ & $1.78 \mathrm{cB}$ & $85.76 \mathrm{aA}$ & $71.78 \mathrm{fB}$ & $58.88 \mathrm{aA}$ & $52.27 \mathrm{bB}$ \\
\hline Acacia erioloba & $56.21 \mathrm{cA}$ & $55.84 \mathrm{bA}$ & $15.16 \mathrm{bA}$ & $14.92 \mathrm{bA}$ & $1.76 \mathrm{aA}$ & $1.77 \mathrm{aA}$ & $6.41 \mathrm{dA}$ & $6.26 \mathrm{cA}$ & $2.18 \mathrm{aA}$ & $2.17 \mathrm{aA}$ & $81.72 \mathrm{cA}$ & $81.07 \mathrm{cB}$ & $50.31 \mathrm{dA}$ & $48.19 \mathrm{cB}$ \\
\hline Acacia haematoxylon & $57.68 \mathrm{bA}$ & $51.50 \mathrm{cB}$ & $14.85 \mathrm{cA}$ & $13.23 \mathrm{eB}$ & $1.74 \mathrm{aA}$ & $1.64 \mathrm{bB}$ & $6.58 \mathrm{bA}$ & $5.88 \mathrm{~dB}$ & $2.11 \mathrm{bA}$ & $1.96 \mathrm{bB}$ & $82.96 \mathrm{bA}$ & $74.21 \mathrm{eB}$ & $55.73 \mathrm{bA}$ & $49.31 \mathrm{bcB}$ \\
\hline Olea europaea & $50.61 \mathrm{fB}$ & $55.74 \mathrm{bA}$ & $14.93 \mathrm{cB}$ & $15.82 \mathrm{aA}$ & $1.50 \mathrm{~dB}$ & $1.62 \mathrm{bA}$ & $6.15 \mathrm{eB}$ & $6.50 \mathrm{bA}$ & $1.88 \mathrm{dA}$ & $1.93 \mathrm{bA}$ & $74.53 \mathrm{eB}$ & $81.61 \mathrm{bA}$ & $45.63 \mathrm{fA}$ & $43.38 \mathrm{fB}$ \\
\hline Acacia mellifera & $54.25 \mathrm{~dB}$ & $61.72 \mathrm{aA}$ & $14.00 \mathrm{~dB}$ & $15.60 \mathrm{abA}$ & $1.57 \mathrm{cB}$ & $1.79 \mathrm{aA}$ & $6.51 \mathrm{cB}$ & $7.29 \mathrm{aA}$ & $1.96 \mathrm{cB}$ & $2.16 \mathrm{aA}$ & $78.29 \mathrm{~dB}$ & $88.55 \mathrm{aA}$ & $47.01 \mathrm{eA}$ & $45.40 \mathrm{eB}$ \\
\hline $\begin{array}{l}\text { Eragrostis } \\
\text { trichopophora }\end{array}$ & $62.13 \mathrm{aA}$ & $56.98 \mathrm{bB}$ & $15.26 \mathrm{abA}$ & $13.54 \mathrm{cdB}$ & $1.63 \mathrm{cA}$ & $1.42 \mathrm{~dB}$ & $6.20 \mathrm{eA}$ & $5.82 \mathrm{~dB}$ & $1.83 \mathrm{dA}$ & $1.76 \mathrm{cA}$ & $87.05 \mathrm{aA}$ & $79.52 \mathrm{~dB}$ & $54.74 \mathrm{cA}$ & $54.4 \mathrm{aA}$ \\
\hline
\end{tabular}


Table 3. Volumes (mL/g DM) of methane produced by browse species with different tannin concentrations supplemented to grass hay at a ratio of $30: 70$ with or without polyethylene glycol

Means with different lower-case letters within a column are significantly $(P<0.001)$ different. Means with different upper-case letters in rows within each incubation time are significantly $(P<0.05)$ different. No PEG, denotes presence of tannin; PEG, denotes absence of tannin

\begin{tabular}{|c|c|c|c|c|c|c|c|c|c|}
\hline \multirow[b]{3}{*}{ Species } & \multirow[b]{3}{*}{ Tannin level } & \multicolumn{8}{|c|}{ Methane production (mL/g DM) } \\
\hline & & \multicolumn{2}{|c|}{$2 \mathrm{~h}$} & \multicolumn{2}{|c|}{$12 \mathrm{~h}$} & \multicolumn{2}{|c|}{$24 \mathrm{~h}$} & \multicolumn{2}{|c|}{$48 \mathrm{~h}$} \\
\hline & & PEG & No PEG & PEG & NO PEG & PEG & No PEG & PEG & NO PEG \\
\hline Acacia luederitzii & High & $0.38 \mathrm{aA}$ & $0.03 \mathrm{~dB}$ & 4.05abA & $0.48 \mathrm{~dB}$ & $14.20 \mathrm{cA}$ & $6.15 \mathrm{~dB}$ & $23.00 \mathrm{cA}$ & $8.93 \mathrm{~dB}$ \\
\hline Monechma incanum & High & $0.35 \mathrm{aA}$ & $0.10 \mathrm{bcB}$ & $4.60 \mathrm{bA}$ & 1.73abcB & 17.20abA & $14.20 \mathrm{bB}$ & $25.08 \mathrm{cA}$ & $16.20 \mathrm{bB}$ \\
\hline Acacia erioloba & Medium & $0.38 \mathrm{aA}$ & $0.25 a B$ & $3.83 \mathrm{bcA}$ & $2.13 a b B$ & $13.33 \mathrm{cdA}$ & $10.88 c B$ & $18.85 \mathrm{dA}$ & $14.20 c B$ \\
\hline Acacia haematoxylon & Medium & $0.33 a b A$ & $0.13 \mathrm{bB}$ & 3.95abA & $1.65 \mathrm{bcB}$ & $12.28 \mathrm{deA}$ & $10.53 c B$ & $18.55 \mathrm{dA}$ & $15.88 \mathrm{bB}$ \\
\hline Olea europaea & Low & $0.33 a b A$ & $0.15 b B$ & $3.28 \mathrm{cdA}$ & 2.10abB & $11.05 \mathrm{efA}$ & $10.98 c A$ & $18.90 \mathrm{dA}$ & $16.05 \mathrm{bB}$ \\
\hline Acacia mellifera & Low & $0.23 \mathrm{bA}$ & $0.10 \mathrm{bcB}$ & $2.68 \mathrm{deA}$ & $1.18 \mathrm{cB}$ & $9.33 f A$ & $9.08 c A$ & $15.78 \mathrm{cA}$ & $14.80 \mathrm{cbB}$ \\
\hline Eragrostis trichopophora & No tannin & $0.10 \mathrm{cA}$ & $0.05 \mathrm{cA}$ & $2.80 \mathrm{deA}$ & $2.28 \mathrm{aB}$ & $18.78 \mathrm{aA}$ & $17.63 a \mathrm{~B}$ & 39.93aA & $33.95 a B$ \\
\hline s.e.m. & & 0.17 & 0.01 & 0.089 & 0.08 & 0.258 & 0.309 & 0.32 & 0.338 \\
\hline$P$ & & $<0.001$ & $<0.001$ & $<0.001$ & $<0.001$ & $<0.001$ & $<0.001$ & $<0.001$ & $<0.001$ \\
\hline
\end{tabular}


Table 4. Ratio of methane to some fermentation parameters produced by browse species with different tannin concentrations supplemented to grass hay at a ratio of $30: 70$ with or without polyethylene glycol

Means with different lower-case letters within a column are significantly $(P<0.05)$ different. Means with different upper-case letters in rows within each incubation time are significantly $(P<0.05)$ different. No PEG, denotes presence of tannin; PEG, denotes absence of tannin. $\mathrm{CH}_{4}$, methane; IVOMD, in vitro organic matter digestibility; VFA, volatile fatty acid

\begin{tabular}{llcccccc} 
& & \multicolumn{2}{c}{$\mathrm{CH}_{4} /$ total gas } & \multicolumn{2}{c}{$\mathrm{CH}_{4} / \mathrm{VFA}$} & \multicolumn{2}{c}{$\mathrm{CH}_{4} / \mathrm{IVOMD}^{\mathrm{V}}$} \\
Species & Tannin level & PEG & No PEG & PEG & No PEG & PEG & No PEG \\
\hline Acacia luederitzii & High & $0.085424 \mathrm{bA}$ & $0.05327 \mathrm{~dB}$ & $0.195162 \mathrm{bA}$ & $0.086571 \mathrm{cB}$ & $0.241538 \mathrm{cA}$ & $0.129446 \mathrm{~dB}$ \\
Monechma incanum & High & $0.104955 \mathrm{bB}$ & $0.105852 \mathrm{bB}$ & $0.20056 \mathrm{bA}$ & $0.197827 \mathrm{bB}$ & $0.29212 \mathrm{bA}$ & $0.271666 \mathrm{bB}$ \\
Acacia erioloba & Medium & $0.094573 \mathrm{bA}$ & $0.082782 \mathrm{bB}$ & $0.163118 \mathrm{cA}$ & $0.134205 \mathrm{cB}$ & $0.264957 \mathrm{cA}$ & $0.225773 \mathrm{cB}$ \\
Acacia haematoxylon & Medium & $0.076188 \mathrm{cB}$ & $0.079604 \mathrm{cA}$ & $0.148023 \mathrm{dA}$ & $0.141895 \mathrm{bB}$ & $0.220348 \mathrm{dA}$ & $0.213547 \mathrm{cB}$ \\
Olea europaea & Low & $0.087978 \mathrm{bcB}$ & $0.095106 \mathrm{bA}$ & $0.148262 \mathrm{dA}$ & $0.134542 \mathrm{bB}$ & $0.242165 \mathrm{cB}$ & $0.253112 \mathrm{bA}$ \\
Acacia mellifera & Low & $0.077184 \mathrm{cB}$ & $0.07993 \mathrm{cA}$ & $0.119172 \mathrm{eA}$ & $0.102541 \mathrm{cB}$ & $0.198468 \mathrm{eB}$ & $0.20 \mathrm{bA}$ \\
Eragrostis trichopophora & No tannin & $0.119238 \mathrm{aA}$ & $0.113013 \mathrm{aA}$ & $0.215738 \mathrm{aB}$ & $0.221705 \mathrm{aA}$ & $0.343076 \mathrm{aA}$ & $0.324081 \mathrm{aA}$ \\
\hline
\end{tabular}




\section{In vitro enteric $\mathrm{CH} 4$ production}

There were significant differences $(P<0.001)$ between the different browse species in terms of the in vitro $\mathrm{CH}_{4}$ production after $48 \mathrm{~h}$ of incubation (Table 3 ). The result shows that the tannin concentration of the browse species played a significant role in suppressing methanogenic activities. Substrates containing high tannin browse reported greatest reduction in $\mathrm{CH}_{4}$ production followed by substrate with medium tannin and least in the substrate with low tannin concentration. The relationship between tannin concentration in the browse species and $\mathrm{CH}_{4}$ production at $48 \mathrm{~h}$ in vitro was very significant (Fig. 1). The proportion of $\mathrm{CH}_{4}$ in the total gas produced and the ratio of $\mathrm{CH}_{4}$ produced to IVOMD was lower with increase in the level of tannin in the browse species as indicated by the differences in $\mathrm{CH}_{4}$ to total gas ratio between incubations with PEG and those without PEG (Table 4). However, $\mathrm{CH}_{4}$ produced per unit of total VFA increased with the concentration of tannin in the browse species (Fig. 2).

Fig. 1. Effects of tannin concentration of browse species on 48-h methane production in a browse-grass substrate $(30: 70)$ with or without polyethylene glycol.

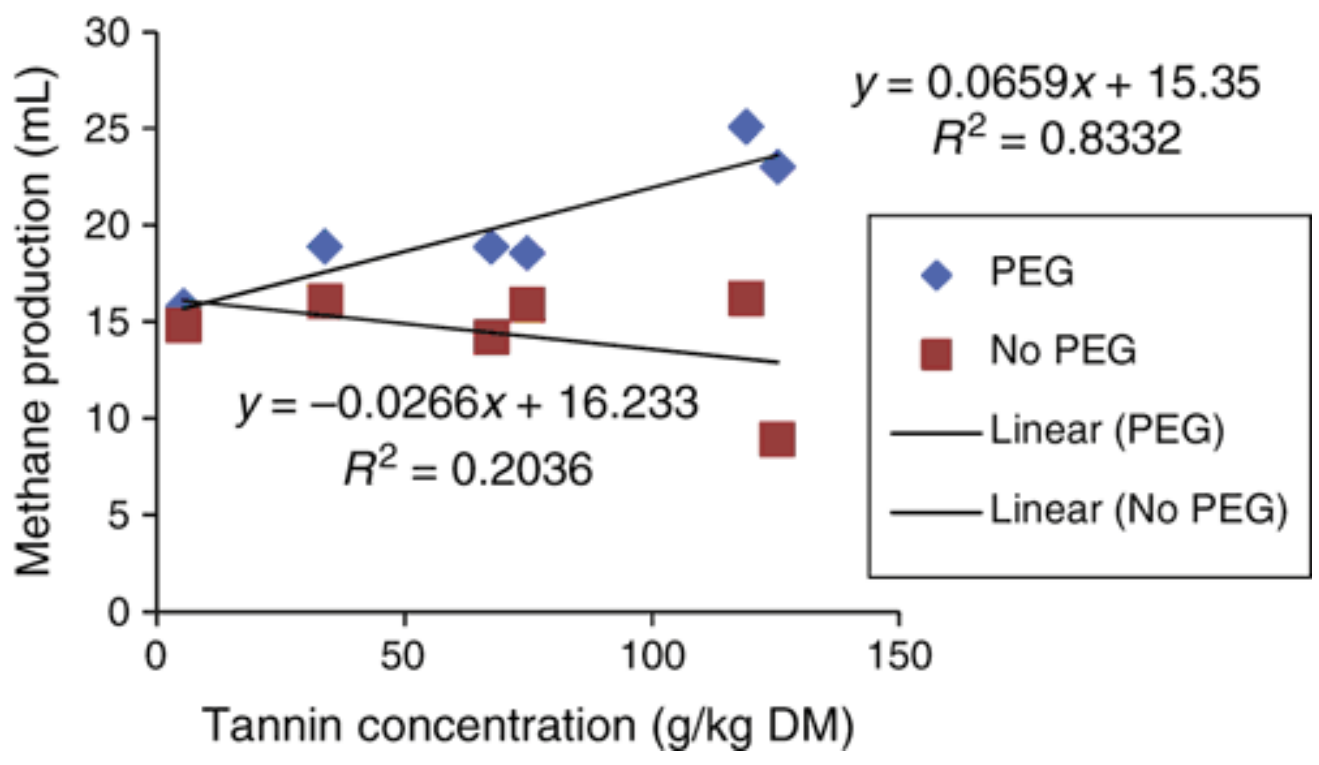


Fig. 2. Effects of tannin concentration of browse species on the ratio of methane to volatile fatty acid production in a browse-grass substrate $(30: 70)$ with or without polyethylene glycol.

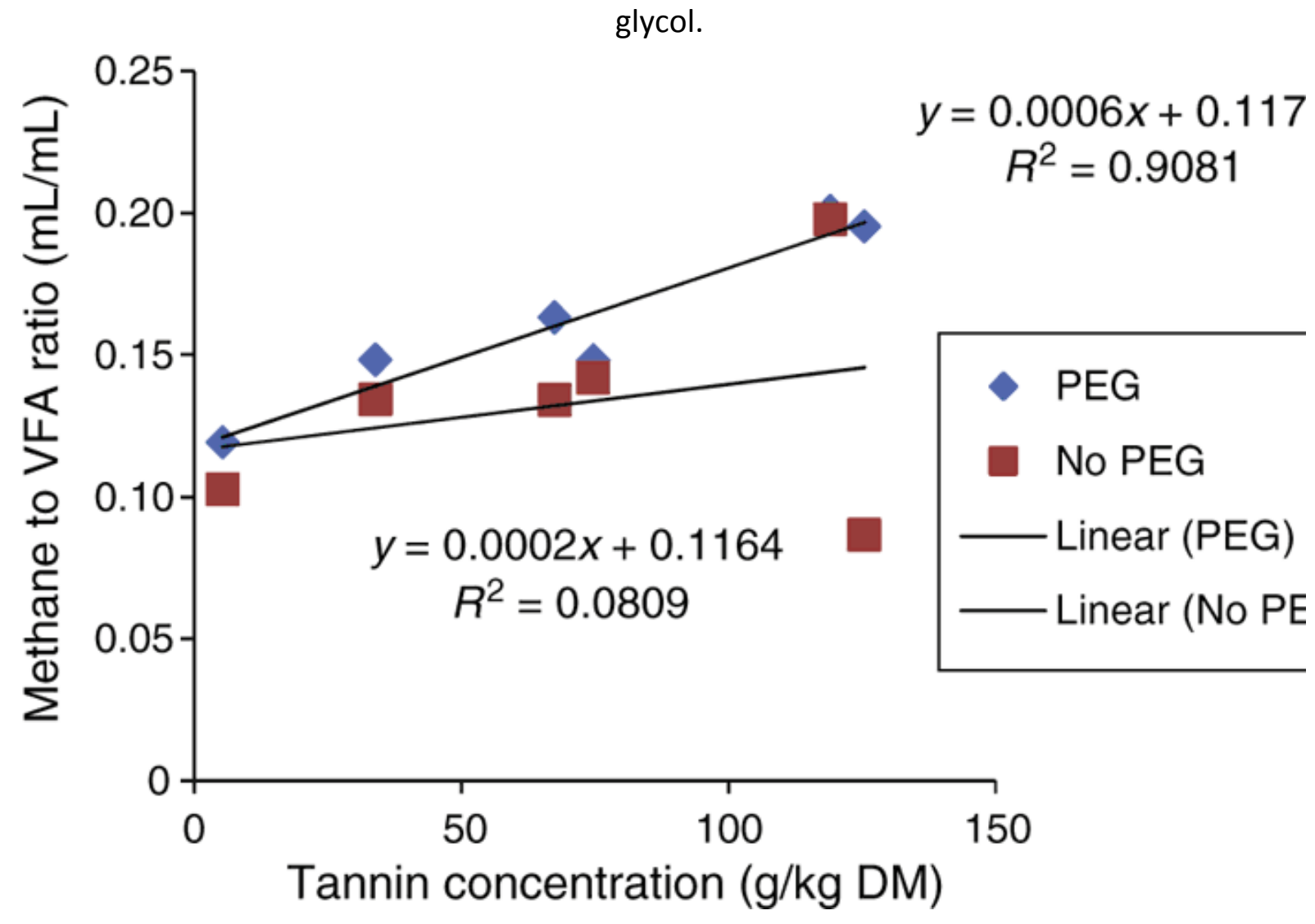

The total amount of $\mathrm{CH}_{4}$ produced after $24 \mathrm{~h}$ in vitro incubation was decreased by $61.17 \%$ in substrate containing $A$. luederitzii and $35.41 \%$ in $M$. incanum associated with the inhibitory effects of their tannins on $\mathrm{CH}_{4}$ whereas $O$. europaea and $A$. mellifera did not show significant effect on $\mathrm{CH}_{4}$ reduction at 24-h incubation. The cumulative $\mathrm{CH}_{4}$ production at 48$\mathrm{h}$ incubation was decreased by $61.2 \%, 43.6 \%, 24.7 \%$ and $14.4 \%$ in A. luederitzii, $M$. incanum, A. erioloba and $A$. haematoxylon, respectively. The efficacy of $\mathrm{CH}_{4}$ reduction can be associated to their tannin concentrations, which may indicate direct inhibition of methanogenesis, fermentation of organic matter or their inhibitory effects on ciliate protozoa (Hess et al. 2003).

The action of CT on methanogenesis has been attributed partly to indirect effects of reduced hydrogen production and organic matter digestibility, and partly by direct inhibitory effects on methanogens (Monforte-Briceño et al. 2005; Tavendale et al. 2005). Hess et al. (2004) reported that in vitro $\mathrm{CH}_{4}$ production decreased when Calliandra tannins were supplemented to a tropical grass substrate as was observed when A. luederitzii and $M$. incanum was supplemented to $E$. trichopophora. This further confirms earlier reports that CT will lower $\mathrm{CH}_{4}$ emission by ruminants (Carulla et al. 2005; Puchala et al. 2005). Browse species with higher $\mathrm{CT}$ concentrations such as in $A$. luederitzii and $M$. incanum have good potential to reduce $\mathrm{CH}_{4}$ concentrations as observed in previous studies (Getachew et al. 2008; Bhatta et al. 2009). Carulla et al. (2005) reported that when sheep were fed a mixture of $L$. perenne and $T$. pratense or when $M$. sativa was supplemented with $29 \mathrm{~g} \mathrm{CT} / \mathrm{kg}$ dietary DM of $A$. mearnsii, $\mathrm{CH}_{4}$ emission was reduced by $130 \mathrm{~kJ}$. However, a limited number of studies investigated the direct and indirect effects of plant secondary components on $\mathrm{CH}_{4}$ 
Table 5. Loss of energy as methane (MJ/g DM) produced by browse species with different tannin concentrations supplemented to grass hay at a ratio of $30: 70$ with or without polyethylene glycol

Means with different lower-case letters within a column are significantly $(P<0.05)$ different. Means with different upper-case letters in rows within each incubation time are significantly $(P<0.05)$ different. No PEG, denotes presence of tannin; PEG denotes absence of tannin. $\mathrm{CH}_{4}$, methane; IVOMD, in vitro organic matter digestibility; GE, gross energy

\begin{tabular}{|c|c|c|c|c|c|c|c|c|c|c|}
\hline \multirow[b]{2}{*}{ Species } & \multirow[b]{2}{*}{ Tannin level } & \multirow[t]{2}{*}{ GE (MJ/kg) } & \multicolumn{2}{|c|}{$\mathrm{CH}_{4}(\mathrm{~mL})$} & \multicolumn{2}{|c|}{$\mathrm{CH}_{4}(\mathrm{~g} / \mathrm{Kg})$} & \multicolumn{2}{|c|}{ Methane (g/Kg IVOMD) } & \multicolumn{2}{|c|}{ GE loss as methane ( $\mathrm{MJ} / \mathrm{Kg}$ ) } \\
\hline & & & PEG & No PEG & PEG & No PEG & PEG & No PEG & PEG & No PEG \\
\hline Acacia luederitzii & High & 20.2 & 14.2 & 6.15 & 10.22 & 4.43 & 17.39 & 9.32 & $0.60 \mathrm{bA}$ & $0.40 \mathrm{cB}$ \\
\hline Monechma incanum & High & 16.9 & 17.2 & 14.2 & 12.38 & 10.22 & 21.03 & 19.56 & $0.60 \mathrm{bB}$ & $0.63 \mathrm{bA}$ \\
\hline Acacia erioloba & Medium & 19.1 & 13.33 & 10.88 & 9.59 & 7.83 & 19.07 & 16.25 & $0.72 \mathrm{bA}$ & $0.64 \mathrm{bB}$ \\
\hline Acacia haematoxylon & Medium & 20.2 & 12.28 & 10.53 & 8.84 & 7.58 & 15.86 & 15.37 & $0.57 c B$ & $0.63 c A$ \\
\hline Olea europaea & Low & 18.1 & 11.05 & 10.98 & 7.96 & 7.9 & 17.43 & 18.22 & $0.69 b B$ & $0.76 \mathrm{bA}$ \\
\hline Acacia mellifera & Low & 17.7 & 9.33 & 9.08 & 6.71 & 6.53 & 14.28 & 14.39 & $0.54 c B$ & $0.56 \mathrm{cA}$ \\
\hline Eragrostis trichopophora & No tannin & 11.4 & 18.78 & 17.63 & 13.52 & 12.69 & 24.7 & 23.33 & $1.07 \mathrm{aA}$ & $1.16 \mathrm{aA}$ \\
\hline
\end{tabular}


production in animals, and it is difficult to provide a comprehensive assessment at this stage about the magnitude of decrease that might be realistically expected in in vivo research.

\section{Loss of energy as $\mathrm{CH}_{4}$}

Grass-browse substrate containing high tannin browse species significantly decreased the amount of feed gross energy converted to $\mathrm{CH}_{4}$ with $\mathrm{A}$. luederitzii recording the least gross energy loss and $O$. europaea having the highest gross energy loss. According to MonforteBriceño et al. (2005) and Tavendale et al. (2005), the action of CT on methanogenesis can be attributed to the indirect effects of reduced hydrogen production and organic matter digestibility, and by direct inhibitory effects on methanogens. Plant attributes that influence the amount of $\mathrm{CH}_{4}$ produced in a sample are those chemical components that increase its fermentation potential, such as high crude protein, gross energy, organic matter digestibility values and low acid detergent lignin concentrations. In Table $5, \mathrm{CH}_{4}$ production was expressed as a ratio of gas volume, VFA and IVOMD with or without PEG and the ratios were significantly $(P<0.001)$ lower in substrates without PEG compared with the browse grasssubstrates with PEG. The lower ratios for $\mathrm{CH}_{4}: \mathrm{GP}_{24}, \mathrm{CH}_{4}$ : VFA and $\mathrm{CH}_{4}$ : IVOMD that were observed for $A$. luederitzii is partly due to $A$. luederitzii having higher fermentation properties compared with the other browse-grass substrates, but is also related to the tannin concentrations that reduced $\mathrm{CH}_{4}$ production.

\section{Conclusion}

From this study, it can be concluded that the higher the tannin content of browse species, the greater their ability to reduce $\mathrm{CH}_{4}$ concentration, though this correlated with a reduction in organic matter digestibility. Acacia luederitzii reduced $\mathrm{CH}_{4}$ production by more than $55 \%$ over $48 \mathrm{~h}$ of incubation at the expense of $11 \%$ reduction in overall digestibility. Browse species with high tannin composition could therefore be used as a natural alternative to reduce $\mathrm{CH}_{4}$ production. Further research may be required to determine at what concentration tannins can be supplemented to reduce $\mathrm{CH}_{4}$ production without reducing digestibility or animal performance.

\section{Acknowledgements}

The research leading to these results has been conducted as part of the AnimalChange Project, which received funding from the European Community's Seventh Framework Program (FP7/2007-2013) under the grant agreement no. 266018. The authors are grateful for the additional co-funding that was received from the Department of Science and Technology and National Research Foundation, South Africa.

\section{References}

Beauchemin KA, McGinn SM, Martinez TF, McAllister TA (2007) Use of condensed tannin extract from quebracho trees to reduce methane emissions from cattle. Journal of Animal Science 85, 1990-1996. 
Bhatta R, Vaidyanathan S, Shinde AK, Jackmola RC (2005) Effect of feeding complete feed block containing Prosopis cineraria leaves and polyethylene glycol (PEG)-6000 on nutrient intake, its utilization, rumen fermentation pattern and rumen enzyme profile in kids. Journal of the Science of Food and Agriculture 85, 1788-1794.

Bhatta R, Uyeno Y, Tajima K, Takenaka A, Yabumoto Y, Nonaka I, Enishi O, Kurihara M (2009) Difference in the nature of tannins on in vitro ruminal methane and volatile fatty acid production and on methanogenic archaea and protozoal populations. Journal of Dairy Science 92, 5512-5522.

Bodas R, Lopez S, Fernandez M, Garcia-Gonzalez R, Rodriguez AB, Wallace RJ, Gonzalez JS (2008) In vitro screening of the potential of numerous plant species as anti methanogenic feed additives for ruminants. Animal Feed Science and Technology 145, 245-258.

Borris RP (1996) Natural products research: perspectives from a major pharmaceutical company. Journal of Ethnopharmacology 51, 29-38.

Busquet M, Calsamiglia A, Ferret A, Cardozo PW, Kamel C (2005) Effects of cinnamaldehyde and garlic oil on rumen microbial fermentation in a dual flow continuous culture. Journal of Dairy Science 88, 2508-2516.

Callaway TR, Martin SA (1996) Effects of organic acid and monensin treatment on in vitro mixed ruminal microorganism fermentation of cracked corn. Journal of Animal Science 74, 1982-1989.

Carro MD, Ranilla MJ (2003) Influence of different concentrations of disodium fumarate on methane production and fermentation of concentrate feeds by rumen micro-organisms in vitro. British Journal of Nutrition 90, 617-623.

Carulla JE, Kreuzer M, Machmuller A, Hess HD (2005) Supplementation of Acacia mearnsii tannins decrease methanogenesis and urinary nitrogen in forage-fed sheep. Crop and Pasture Science 56, 961-970.

Clapperton JL (1977) Effect of a methane-suppressing compound, trichloroethyl adipate, on rumen fermentation and growth of sheep. Animal Production 24, 169-181.

Crutzen PJ (1995) The role of methane in atmospheric chemistry and climate. In 'Ruminant physiology: digestion, metabolism, growth and reproduction'. (Eds W Von Engelhardt, S LeonhardMarek, G Breves, D Giesecke) pp. 291-316. (Ferdinand Enke Verlag: Stuttgart, Germany)

Engels EAN, Van der Merwe FJ (1967) Application of an in vitro technique to South African forages with special reference to the effect to certain factors on the results. South African Journal of Agriculture Science 10, 983-995.

García-González R, Lopez S, Fernandez M, Bodas R, Gonzalez JS (2008) Screening the activity of plants and spices for decreasing ruminal methane production in vitro. Animal Feed Science and 
Technology 147, 36-52.

Getachew G, Pittroff W, Putnam DH, Dandekar A, Goyal S, DePeters EJ (2008) The influence of addition of gallic acid, tannic acid, or quebracho tannins to alfalfa hay on in vitro rumen fermentation and microbial protein synthesis. Animal Feed Science and Technology 140, 444-461.

Gibbs MJ, Lewis L, Hoffman JS (1989) 'Reducing methane emissions from livestock: opportunities and issues.' (U.S. Environmental Protection Agency: Washington, DC)

Goel G, Arvidsson K, Vlaeminck B, Bruggeman G, Descepper K, Fievez V (2009) Effects of capric acid on rumen methanogenesis and biohydrogenation on linoleic and á-linolenic acid. Animal 3, 810-816.

Goering HK, Van Soest PJ (1970) Forage Fiber Analyses (Apparatus, reagents, procedures and some applications). USDA Agricultural Handbook No. 379. Agricultural Research Service, United States Department of Agriculture.

Grant RJ, Mertens DR (1992) Impact of in vitro fermentation techniques upon kinetics of fiber digestion. Journal of Dairy Science 75, 1263-1272.

Guo Y, Liu Y, Lu Y, Zhu W, Denman S, McSweeney CS (2008) Effect of tea saponin on methanogenesis, microbial community structure and expression of mcrA gene, in cultures of rumen micro-organisms. Letters in Applied Microbiology 47, 421-426.

Hess HD, Monsalve LM, Lascano CE, Carulla JE, Diaz TE, Kreuzer M (2003) Supplementation of a tropical grass diet with forage legumes and Sapindus saponaria fruits: effects on in vitro ruminal nitrogen turnover and methanogenesis. Australian Journal of Agricultural Research 54, 703-713.

Hess HD, Valencia FL, Monsalve LM, Lascano CE, Kreuzer M (2004) Effects of tannins in Calliandra calothyrsus and supplemental molasses on ruminal fermentation in vitro. Journal of Animal and Feed Sciences 13, 95-98.

Hu WL, Liu JX, Ye JA, Wu YM, Guo YQ (2005) Effect of tea saponin on rumen fermentation in vitro. Animal Feed Science and Technology 120, 333-339.

Johnson KA, Johnson DE (1995) Methane emissions from cattle. Journal of Animal Science 73, 24832492.

Kamra DN, Agarwal N, Chaudhary LC (2006) Inhibition of ruminal methanogens by tropical plants containing secondary compounds. International Congress Series 1293, 156-163.

Khiaosa-Ard R, Bryner SF, Scheeder MRL, Wettstein HR, Leiber F, Kreuzer M, Soliva CR (2009) Evidence for the inhibition of the terminal step of ruminal alphalinolenic acid biohydrogenation by condensed tannins. Journal of Dairy Science 92, 177-188. 
Lila ZA, Mohammed N, Kanda S, Kamada T, Itabashi M (2003) Effect of sarsaponin on ruminal fermentation with particular reference to methane production in vitro. Journal of Dairy Science 86, 3330-3336.

Lourenco M, Cardozo PW, Calsamiglia S, Fievez V (2008) Effects of saponins, quercetin, eugenol, and cinnamaldehyde on fatty acid biohydrogenation of forage polyunsaturated fatty acids in dual-flow continuous culture fermenters. Journal of Animal Science 86, 3045-3053.

Martin C, Morgavi DP, Doreau M (2010) Methane mitigation in ruminants: from microbe to the farm scale. Animal 4, 351-365.

McDonald P, Edwards RA, Greenhalgh JFD, Morgan CA (2002) 'Animal nutrition.' (Pearson Education Ltd: Harlow, Essex)

Monforte-Briceño G, Sandoval-Castro CA, Ramirez-Aviles L, Capetillo Leal CM (2005) Defaunating capacity of tropical fodder trees: effects of polyethylene glycol and its relationship to in vitro gas production. Animal Feed Science and Technology 123-124, 313-327.

Mould FL, Morgan R, Kliem KE, Krystallidou E (2005) A review and simplification of the in vitro incubation medium. Animal Feed Science and Technology 123-124, 155-172.

Nagaraja TG, Newbold CJ, Van Nevel CJ, Demeyer DI (1997) Manipulation of ruminal fermentation. In 'The rumen microbial ecosystem'. (Eds PN Hobson, CS Stewart) pp. 523-632. (Springer: Dordrecht, The Netherlands)

Patra AK, Saxena J (2010) A new perspective on the use of plant secondary metabolites to inhibit methanogenesis in the rumen. Phytochemistry 71, 1198-1222.

Patra AK, Kamra DN, Agarwal N (2006) Effect of plant extracts on in vitro methanogenesis, enzyme activities and fermentation of feed in rumen liquor of buffalo. Animal Feed Science and Technology 128, 276-291.

Pellikaan WF, Stringano E, Leenaars J, Bongers LGM, Van Laar-Van Schuppen S, Plant J, MuellerHarvey I (2011) Evaluating effects of tannins on extent and rate of in vitro gas and $\mathrm{CH} 4$ production using an automated pressure evaluation system (APES). Animal Feed Science and Technology 166167, 377-390.

Puchala R, Min BR, Goetsch AL, Sahlu T (2005) The effect of condensed tannin-containing forage on methane emission by goats. Journal of Animal Science 83, 182-186.

Santoso B, Mwenya B, Sar C, Takahashi J (2007) Methane production and energy partition in sheep fed timothy hay silage- or hay-based diets. Journal of Animal Science and Veterinary 12, 27-33. [JITV]

SAS (2010) 'SAS version 9.3.' (SAS Institute Inc.: Cary, NC) 
Soliva CR, Zeleke AB, Clement C, Hess HD, Fievez V, Kreuzer M (2008) In vitro screening of various tropical foliages, seeds, fruits and medicinal plants for low methane and high ammonia generating potentials in the rumen. Animal Feed Science and Technology 147, 53-71.

Tavendale MH, Meagher LP, Pacheco D, Walker N, Attwood GT, Sivakumaran S (2005) Methane production from in vitro rumen incubations with Lotus pedunculatus and Medicago sativa, and effects of extractable condensed tannin fractions on methanogenesis. Animal Feed Science and Technology 123-124, 403-419.

Theodorou MK, Williams BA, Dhanoa MS, McAllen AB, France J (1994) A simple gas production method using pressure transducers to determine the fermentation kinetics of ruminant feed. Animal Feed Science and Technology 48, 185-197.

Tilley JMA, Terry RA (1963) A two-stage technique for the in vitro digestion of forage crops. Grass and Forage Science 18, 104-111.

Van Nevel CJ, Demeyer DI (1996) Control of rumen methanogenesis. Environmental Monitoring and Assessment 42, 73-97.

Waghorn GC, Shelton ID (1997) Effect of condensed tannins in Lotus corniculatus on the nutritive value of pasture for sheep. The Journal of Agricultural Science (Cambridge) 128, 365-372.

Waghorn GC, Shelton ID, McNabb WC (1994) Effects of condensed tannins in Lotus pedunculatus on its nutritive value for sheep. 1. Non-nitrogenous aspects. The Journal of Agricultural Science 123, 99107.

Wang Y, McAllister TA, Yanke LJ, Xu ZJ, Cheeke PR, Cheng KJ (2000) In vitro effects of steroidal saponins from Yucca schidigera extract on rumen microbial protein synthesis and ruminal fermentation. Journal of the Science of Food and Agriculture 80, 2114-2122. 